\title{
Influence of Working Motivation and Environment on the Employees Bureau Performance of Organization Regional Secretariat in West Sumatera
}

\author{
Yusnaena*, Dedi Julianto dan Fitri Avrima Darma Yoeni \\ Universitas Dharma Andalas \\ Padang, Sumatera Barat, Indonesia \\ *ayuwidara72@gmail.com
}

Received 02 February 2016; Revised 12 March 2016; Accepted 21 June 2016

\begin{abstract}
This study presents the effect of motivation and working environment to employee performance Bureau of the Regional Secretariat of the Organization of West Sumatera province. This study is a survey with a quantitative approach and the data used is primary data obtained by field survey where in total 44 respondents were directly sampled with sample collection census techniques. Hypothesis testing is done by means of multiple linear regression analysis using the three instruments consists of three sets of questionnaires to the variable, motivation, working environment and performance. Based on the results, there are conclusion can be drawn i.e. (1) Working motivation variables affect the performance of employees Organization Bureau of West Sumatera Provincial Secretariat significantly; (2) working environment variables affect the performance of employees Organization Bureau of West Sumatera Provincial Secretariat significantly; (3) Both working motivation and working environment effect on the performance of employees of the Bureau of the Regional Secretariat of the Organization of West Sumatera Province.
\end{abstract}

Keywords: Working motivation; Working environment; Performance; Employee.

\section{Introduction}

The organization has a goal to motivate employees to work more optimally with the ability of each employee. Therefore an organization can undertake a variety of ways for the human resources [7] that exist within the organization may be convenient to perform the sake of achievement of organizational goals, is in need of motivation for employees to work more diligently than targeted $[3,4,5]$. Various efforts by the organization to motivate employees so that employees can be disciplined in work, not just provide facilities sufficient alone but a government agency such as the Bureau of Organization Provincial Secretariat of West Sumatera can provide motivation to work to each employee with the means and infrastructure such as financial and non financial compensation, where they can motivate employees. According to Handoko in [19], is the state of one's personal motivation that drives the desire of individuals to undertake certain activities in order to achieve the goal. Bureau of Regional Secretariat of the Organization of West Sumatera Province, located in the office of the Governor of West Sumatera province which is the headquarters of West Sumatera provincial administration which has a number of employees 44 people and is divided into 4 parts in his 13 people at the institutional, management of 9 parts, 15 parts of the performance and 7 on the utilization of the apparatus.

This institution is indirectly needed by employees who actually have high motivation and request conducive working environment $[16,17,18]$. Therefore, it can make employees feel comfortable, because the environment is to have the greatest effect on the incidence of the motivation for the performance of employees in an institution [11,15]. According to Nitisemito in [8], the working environment as everything that is around the workers who can influence him in carrying out the tasks entrusted. Performance or achievements of the work is a work that is accomplished person in 
performing duties assigned to him based on skills, experience, and determination as well as time. Simanjuntak in [13] states that the intended the performance is the level of achievement for the implementation of certain tasks. According Mangkunagara in [6], that the definition of the performance is the result of the quality and quantity of work achieved by an employee in carrying out their duties in accordance with the responsibilities given to him.

The research issues that will be discussed is "The influence of motivation and working environment Employee Performance against Regional Secretariat of the Organization Bureau of West Sumatera province. This study is aimed to examine the dimensions of motivation and working environment of employees on the performance of the Regional Secretariat of the Organization Bureau Employees West Sumatera province, Motivation according to Hasibuan in [20], is powering the motion of a person who created excitement to get them to cooperate, to work effectively and integrated with all efforts to achieve satisfactionsed on the description in the background.

The rest of this paper is organized as follow. Section 2 describes proposed methodology. Section 3 presents results and following by discussion. Finally, the conclusion of this work is presented in Section 4.

\section{Methodology}

The research model for study the influence of working motivation and environment on the employees bureau performance of Organization Regional Secretariat in West Sumatera is given in Figure 1 as follow:

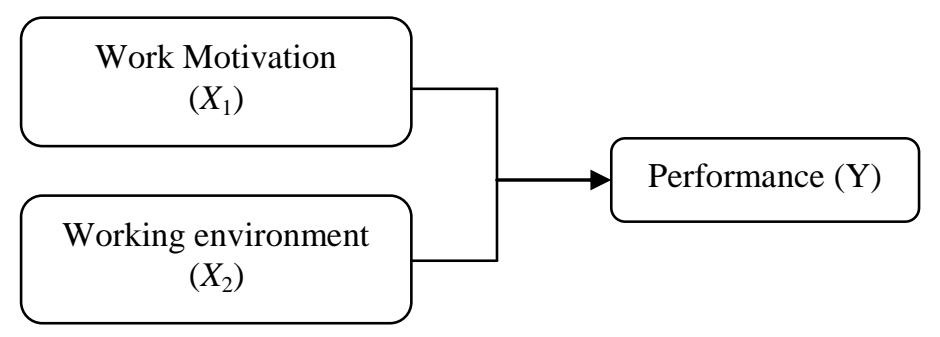

Figure 1: Research model

This study is a survey with a quantitative approach $[2,1$

4], which aims to determine the effect of motivation and working environment to employee performance Organization Regional Secretariat of West Sumatera Province. The data used is primary data obtained by field survey. Hypothesis testing is done by means of multiple linear regression analysis population in this study were all employees of the Bureau of the Regional Secretariat of the Organization of West Sumatera Province totaling 44 respondents were directly sampled with sample collection techniques census.

\section{Results And Discussion}

\subsection{Descriptive Analysis}

Total Achievement Respondents (TCR) i.e. the level of achievement of the respondents is used to test and determine the level of achievement of the answers of the respondents (See Table 1).

Table 1: Description of respondents answer working motivation

\begin{tabular}{|c|c|c|c|c|c|c|c|c|c|c|}
\hline \multirow[b]{2}{*}{ No } & Variable / Indicator & \multicolumn{5}{|c|}{ SCORE SCORE } & \multirow[b]{2}{*}{$\mathrm{Ttl}$} & \multirow[b]{2}{*}{ Mean } & \multirow[b]{2}{*}{ TCR } & \multirow[b]{2}{*}{ Des } \\
\hline & Working motivation variable $\mathrm{X} 1$ & $\begin{array}{c}S S \\
5\end{array}$ & $\begin{array}{l}\mathrm{S} \\
4\end{array}$ & $\begin{array}{c}\mathrm{KS} \\
3\end{array}$ & $\begin{array}{c}\mathrm{TS} \\
3\end{array}$ & $\begin{array}{c}\text { STS } \\
1\end{array}$ & & & & \\
\hline \multicolumn{11}{|c|}{ Physiological Needs } \\
\hline
\end{tabular}




\begin{tabular}{|c|c|c|c|c|c|c|c|c|c|c|}
\hline 1 & $\begin{array}{l}\text { I think the Bureau of Organization of } \\
\text { West Sumatera Provincial Secretariat } \\
\text { has provided an ideal resting time }\end{array}$ & 10 & 17 & 17 & & & 44 & 3,84 & $76,8 \%$ & $\begin{array}{l}\text { high } \\
\text { enoug }\end{array}$ \\
\hline 2 & $\begin{array}{l}\text { Hours worked in the Bureau of the } \\
\text { Regional Secretariat of the } \\
\text { Organization of West Sumatera } \\
\text { Province is according to my capacity }\end{array}$ & 7 & 29 & 4 & 2 & 2 & 44 & 3,84 & $76,8 \%$ & $\begin{array}{l}\text { high } \\
\text { enoug }\end{array}$ \\
\hline 3 & $\begin{array}{l}\text { Bureau of Regional Secretariat of the } \\
\text { Organization of West Sumatera } \\
\text { province is providing benefits to } \\
\text { employees in the form of staple }\end{array}$ & 13 & 28 & 3 & & & 44 & 4,23 & $84,6 \%$ & high \\
\hline 4 & $\begin{array}{l}\text { Salary that I receive today is in } \\
\text { conformity with the amount of work I } \\
\text { am doing }\end{array}$ & 10 & 31 & 3 & & & 44 & 4,16 & $83,2 \%$ & high \\
\hline 5 & $\begin{array}{l}\text { Cooperative Organization Bureau of } \\
\text { West Sumatera Provincial Secretariat } \\
\text { always lend money that employees are } \\
\text { required }\end{array}$ & 13 & 25 & 6 & & & 44 & 4,16 & $83,2 \%$ & high \\
\hline 6 & $\begin{array}{l}\text { There was no difference in any case } \\
\text { with my colleagues so that motivated } \\
\text { the spirit of work }\end{array}$ & 9 & 32 & 2 & 1 & & 44 & 4,11 & $82,2 \%$ & high \\
\hline 7 & $\begin{array}{l}\text { Agencies give a bonus to me for the } \\
\text { work satisfactory }\end{array}$ & 7 & 31 & 6 & & & 44 & 4,02 & $80,4 \%$ & high \\
\hline \multicolumn{11}{|c|}{ Safety needs } \\
\hline 1 & $\begin{array}{l}\text { I worked obtain insurance guarantee } \\
\text { safety in establishments that I was } \\
\text { motivated and comfortable working }\end{array}$ & 10 & 28 & 6 & & & 44 & 4,09 & $81,8 \%$ & high \\
\hline 2 & $\begin{array}{l}\text { Payroll system at the Bureau of the } \\
\text { Regional Secretariat of the } \\
\text { Organization of West Sumatera } \\
\text { province is already meeting the needs } \\
\text { of a decent life for me }\end{array}$ & 7 & 28 & 9 & & & 44 & 3,95 & $79 \%$ & $\begin{array}{l}\text { high } \\
\text { enough }\end{array}$ \\
\hline 3 & $\begin{array}{l}\text { Bureau of Regional Secretariat of the } \\
\text { Organization of West Sumatera } \\
\text { province has been implemented with } \\
\text { good career development system }\end{array}$ & 13 & 29 & 2 & & & 44 & 4,25 & $85 \%$ & high \\
\hline 4 & $\begin{array}{l}\text { A harmonious working relationship } \\
\text { among employees makes me } \\
\text { comfortable in work }\end{array}$ & 14 & 26 & 4 & & & 44 & 4,23 & $84,6 \%$ & high \\
\hline 5 & $\begin{array}{l}\text { Bureau of Regional Secretariat of the } \\
\text { Organization of West Sumatera } \\
\text { province is always concerned with the } \\
\text { welfare of employees }\end{array}$ & 17 & 21 & 6 & & & 44 & 4,25 & $85 \%$ & high \\
\hline 6 & $\begin{array}{l}\text { Bureau of Regional Secretariat of the } \\
\text { Organization of West Sumatera } \\
\text { province has set K3 programs (health } \\
\text { and safety) are ideal }\end{array}$ & 13 & 22 & 4 & 5 & & 44 & 3,98 & $79,6 \%$ & $\begin{array}{l}\text { high } \\
\text { enough }\end{array}$ \\
\hline 7 & $\begin{array}{l}\text { Management Bureau of the Regional } \\
\text { Secretariat of the Organization of } \\
\text { West Sumatera province provide } \\
\text { overtime for employees with adequate } \\
\text { overtime wages }\end{array}$ & 12 & 28 & 3 & 1 & & 44 & 4,16 & $83,2 \%$ & high \\
\hline 8 & $\begin{array}{l}\text { Each policy in the Bureau of the } \\
\text { Regional Secretariat of the } \\
\text { Organization of West Sumatera } \\
\text { province does not conflict with my } \\
\text { conscience }\end{array}$ & 11 & 27 & 2 & 4 & & 44 & 4,02 & $80,4 \%$ & high \\
\hline 9 & $\begin{array}{l}\text { Performance appraisal system in the } \\
\text { Bureau of the Regional Secretariat of } \\
\text { the Organization of West Sumatera } \\
\text { province was conducted fairly and } \\
\text { objectively }\end{array}$ & 11 & 20 & 13 & & & 44 & 3,95 & $79 \%$ & \begin{tabular}{|l|} 
high \\
enough
\end{tabular} \\
\hline
\end{tabular}




\begin{tabular}{|c|c|c|c|c|c|c|c|c|c|}
\hline \multicolumn{10}{|c|}{ Social needs } \\
\hline 1 & $\begin{array}{l}\text { Bosses always gives encouragement to } \\
\text { me to finish the job }\end{array}$ & 11 & 29 & 4 & & 44 & 4,16 & $83,2 \%$ & high \\
\hline 2 & $\begin{array}{l}\text { I am always ready to help co-workers, } \\
\text { if they have difficulty in completing } \\
\text { its work }\end{array}$ & 11 & 27 & 6 & & 44 & 4,11 & 82,2 & high \\
\hline 3 & $\begin{array}{l}\text { I have the opportunity to socialize } \\
\text { with colleagues outside working hours }\end{array}$ & 13 & 30 & 1 & & 44 & 4,27 & $82,2 \%$ & high \\
\hline 4 & $\begin{array}{l}\text { I am very happy to work with my } \\
\text { colleagues }\end{array}$ & 14 & 27 & 3 & & 44 & 4,25 & $85 \%$ & high \\
\hline 5 & $\begin{array}{l}\text { I feel my mind valued in the Regional } \\
\text { Secretariat of the Organization Bureau } \\
\text { of West Sumatera Province }\end{array}$ & 16 & 26 & 2 & & 44 & 4,32 & $86,4 \%$ & high \\
\hline 6 & $\begin{array}{l}\text { I have not contributed significantly to } \\
\text { the Bureau of the Regional Secretariat } \\
\text { of the Organization of West Sumatera } \\
\text { Province }\end{array}$ & 13 & 28 & 3 & & 44 & 4,23 & $84,6 \%$ & high \\
\hline 7 & $\begin{array}{l}\text { Interaction with colleagues outside the } \\
\text { Bureau of the Regional Secretariat of } \\
\text { the Organization of West Sumatera } \\
\text { province is well established }\end{array}$ & 10 & 31 & 2 & 1 & 44 & 4,14 & $82,8 \%$ & high \\
\hline 8 & $\begin{array}{l}\text { Superiors and colleagues at work } \\
\text { matter to me as Servants so motivated } \\
\text { in my work }\end{array}$ & 12 & 31 & 1 & & 44 & 4,25 & $85 \%$ & high \\
\hline 9 & $\begin{array}{l}\text { Boss open to me to discuss if I have } \\
\text { problems and concerns in the work } \\
\text { that I was motivated to run the next } \\
\text { task }\end{array}$ & 7 & 25 & 12 & & 44 & 3,89 & $77,8 \%$ & $\begin{array}{l}\text { high } \\
\text { enough }\end{array}$ \\
\hline 10 & $\begin{array}{l}\text { Every time I get into trouble, } \\
\text { coworkers would provide relief to me } \\
\text { that I was motivated to cooperate with } \\
\text { colleagues to finish the job }\end{array}$ & 9 & 28 & 7 & & 44 & 4,05 & $81 \%$ & high \\
\hline \multicolumn{10}{|c|}{ The need for an award } \\
\hline 1 & $\begin{array}{l}\text { Bureau of Regional Secretariat of the } \\
\text { Organization of West Sumatera } \\
\text { Province giving awards to employees } \\
\text { who excel }\end{array}$ & 11 & 26 & 7 & & 44 & 4,09 & $81,8 \%$ & high \\
\hline 2 & $\begin{array}{l}\text { Positions that I hold the Bureau of the } \\
\text { Regional Secretariat of the } \\
\text { Organization of West Sumatera } \\
\text { province this affect my social status in } \\
\text { the community }\end{array}$ & 14 & 23 & 7 & & 44 & 4,16 & $83,2 \%$ & high \\
\hline 3 & $\begin{array}{l}\text { Wisdom leadership in the face of } \\
\text { employee encourage me to work } \\
\text { harder }\end{array}$ & 12 & 25 & 7 & & 44 & 4,11 & $82,2 \%$ & high \\
\hline 4 & $\begin{array}{l}\text { n improving my performance given } \\
\text { the opportunity to attend the seminar } \\
\text { as a representative of the Bureau of } \\
\text { the Regional Secretariat of the } \\
\text { Organization of West Sumatera } \\
\text { Province }\end{array}$ & 9 & 29 & 6 & & 44 & 4,07 & $81,4 \%$ & high \\
\hline 5 & $\begin{array}{l}\text { My job as an employee of the Bureau } \\
\text { of the Regional Secretariat of the } \\
\text { Organization of West Sumatera } \\
\text { province increase the social status of } \\
\text { my }\end{array}$ & 10 & 27 & 3 & 4 & 44 & 3,98 & $79,6 \%$ & $\begin{array}{l}\text { high } \\
\text { enough }\end{array}$ \\
\hline 6 & $\begin{array}{l}\text { Leaders gave me the opportunity to } \\
\text { work so that my creativity in the spirit } \\
\text { motivated to work }\end{array}$ & 10 & 23 & 10 & 1 & 44 & 3,93 & $78,6 \%$ & $\begin{array}{l}\text { high } \\
\text { enough }\end{array}$ \\
\hline 7 & $\begin{array}{l}\text { Leaders provide promotion and } \\
\text { advancement opportunities to } \\
\text { employees who have the potential to } \\
\text { develop the potential in working }\end{array}$ & 3 & 30 & 10 & 1 & 44 & 3,77 & $75,4 \%$ & $\begin{array}{l}\text { high } \\
\text { enough }\end{array}$ \\
\hline
\end{tabular}




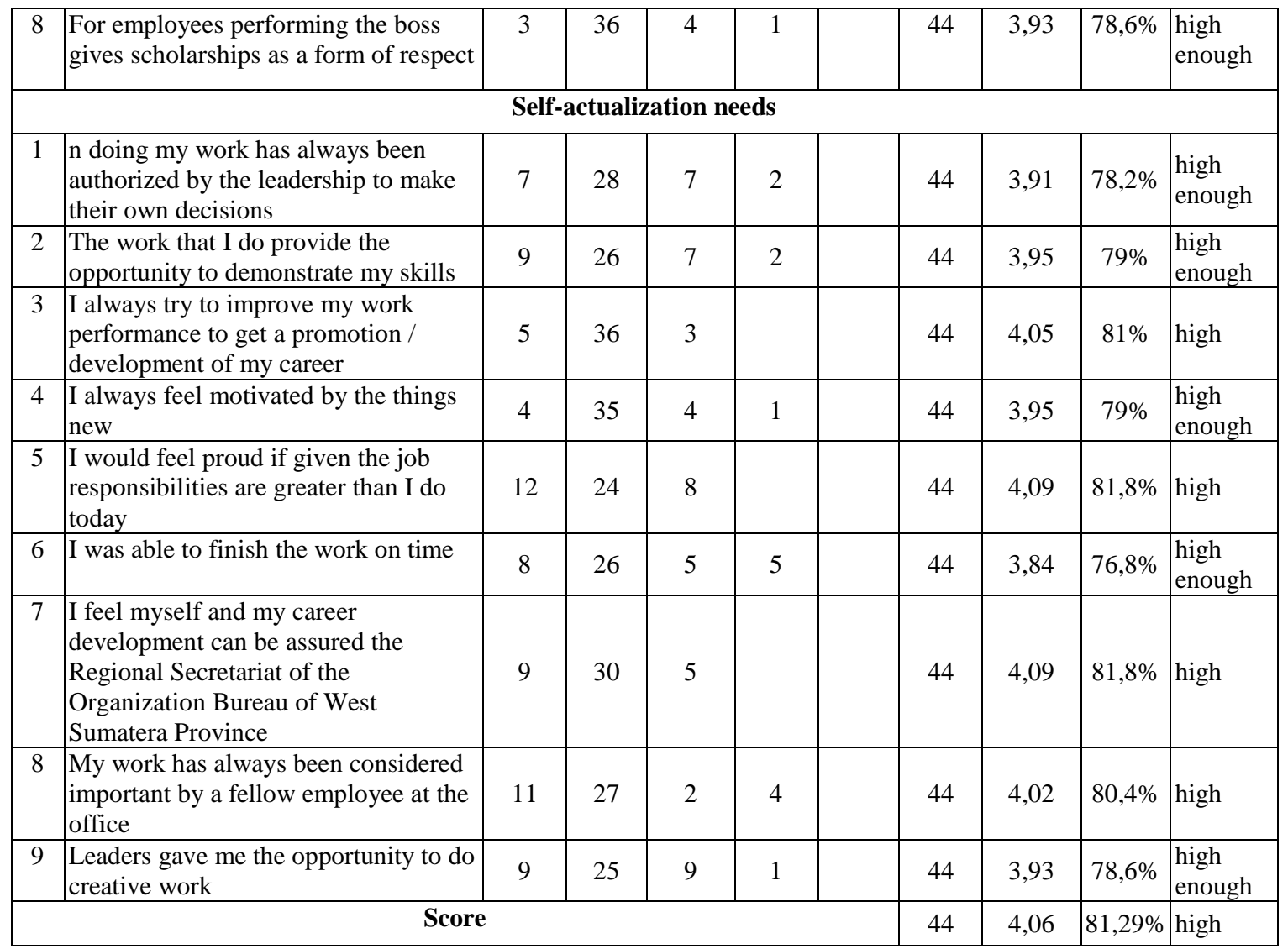

Source: Data processed by SPSS 16

From the Table 1 above, descriptions of respondents to the working motivation on working motivation variable above the highest value on the indicator of social needs item question number 5 is "I feel my thoughts appreciated in the Bureau of the Regional Secretariat of the Organization of West Sumatera province" based on the total achievement of the respondents amounted to $86.4 \%$ so the category is high. It means that employees feel their thoughts are valued at the Bureau of the Regional Secretariat of the Organization of the province of West Sumatera. The lowest value on the indicator would need appreciation item Question 7 is "Leaders provide promotion and advancement opportunities to employees who have the potential to develop the potential of the work", based on the total achievement amounted to $75.4 \%$ of respondents that category includes high enough. It means there is still a given leader for promotion and advancement to employees who have the potential to develop the potential of the work. From an average of 4.06 motivation variable with percentage $81.29 \%$ TCR so that categories including use of high theory can be implemented and verified that according to Hasibuan in [20], the definition of motivation is giving momentum that creates the excitement of a job to get them to cooperate, to work effectively and integrated with all efforts to achieve satisfaction. According Samsuddin in [10], to give an opinion on the definition of motivation is the process from outside influence or push against a person or group of work that they want to implement something that has been set. Motivation is a desire in a person that causes the person to act (Robet L. Mathis and John H. Jacson, 2006). According to Robbins in [9], the motivation is the process that will determine the intensity, direction and persistence of individuals in order to achieve the target. According to Handoko in [19], is the state of one's personal motivation that drives the desire of individuals to undertake certain activities in order to achieve the goal. From the opinion of the experts above can be concluded that motivation is one of encouragement or effort that is certainly capable of giving encouragement for someone to achieve a desired goal and needs to the fullest. 
Table 2: Description of pespondents answers against working environment

\begin{tabular}{|c|c|c|c|c|c|c|c|c|c|c|}
\hline \multirow{3}{*}{ No } & \multirow[b]{2}{*}{ Variabel/indicator } & \multicolumn{5}{|c|}{ SCORE } & \multirow[b]{2}{*}{$\mathrm{Ttl}$} & \multirow[b]{2}{*}{ Mean } & \multirow[b]{2}{*}{ TCR } & \multirow[b]{2}{*}{ Des } \\
\hline & & $\begin{array}{c}\text { SS } \\
5\end{array}$ & $\begin{array}{l}S \\
4\end{array}$ & $\begin{array}{c}\mathrm{KS} \\
3\end{array}$ & $\begin{array}{c}\mathrm{TS} \\
3\end{array}$ & $\begin{array}{c}\text { STS } \\
1\end{array}$ & & & & \\
\hline & Working environment (X2) & & & & & & & & & \\
\hline \multicolumn{11}{|c|}{ Work atmosphere } \\
\hline 1 & $\begin{array}{l}\text { I felt cleanliness in the Bureau of the } \\
\text { Regional Secretariat of the } \\
\text { Organization of West Sumatera } \\
\text { province create a pleasant working } \\
\text { atmosphere }\end{array}$ & 5 & 27 & 9 & 2 & 1 & 44 & 3,75 & $75 \%$ & high enough \\
\hline 2 & $\begin{array}{l}\text { Equation capability without } \\
\text { distinction of status and position make } \\
\text { work atmosphere away from conflict }\end{array}$ & 7 & 28 & 4 & 2 & 3 & 44 & 3,77 & $75,4 \%$ & high enough \\
\hline 3 & $\begin{array}{l}\text { Employee has different achievements } \\
\text { of the labor problems that create an } \\
\text { uncomfortable working environment }\end{array}$ & 14 & 25 & 4 & 1 & & 44 & 4,18 & $83,6 \%$ & High \\
\hline 4 & $\begin{array}{l}\text { Loyalty in activities outside of work } \\
\text { among employees is very good so } \\
\text { brought into good working } \\
\text { atmosphere }\end{array}$ & 11 & 19 & 14 & & & 44 & 3,93 & $78,6 \%$ & high enough \\
\hline 5 & $\begin{array}{l}\text { Employees are abiding by the order } \\
\text { and the value of modesty that makes a } \\
\text { pleasant working atmosphere }\end{array}$ & 6 & 29 & 4 & 3 & 2 & 44 & 3,77 & $75,4 \%$ & high enough \\
\hline \multicolumn{11}{|c|}{ Relationships with colleagues } \\
\hline 1 & $\begin{array}{l}\text { Superiors and colleagues at work } \\
\text { attention to me as Servants }\end{array}$ & 8 & 23 & 13 & & & 44 & 3,89 & $77,8 \%$ & high enough \\
\hline 2 & $\begin{array}{l}\text { I work in accordance with the } \\
\text { organizational structure of the corridor } \\
\text { Bureau of the Regional Secretariat of } \\
\text { the Organization of West Sumatera } \\
\text { Province }\end{array}$ & 11 & 26 & 6 & 1 & & 44 & 4,07 & $81,4 \%$ & high \\
\hline 3 & $\begin{array}{l}\text { here is good cooperation between } \\
\text { employees with their colleagues in the } \\
\text { Bureau of the Regional Secretariat of } \\
\text { the Organization of West Sumatera } \\
\text { Province }\end{array}$ & 11 & 28 & 5 & & & 44 & 4,14 & $82,8 \%$ & high \\
\hline 4 & $\begin{array}{l}\text { There is goodwill within employees to } \\
\text { help each other and relate well with } \\
\text { other employees }\end{array}$ & 11 & 26 & 2 & 5 & & 44 & 3,98 & $79,6 \%$ & high enough \\
\hline 5 & $\begin{array}{l}\text { Co-workers willing to provide } \\
\text { assistance to me every time I get into } \\
\text { trouble }\end{array}$ & 12 & 27 & 5 & & & 44 & 4,16 & $83,2 \%$ & high \\
\hline 6 & $\begin{array}{l}\text { f I have problems and concerns, co- } \\
\text { workers and bosses to help find a way } \\
\text { out and discuss }\end{array}$ & 13 & 25 & 5 & 1 & & 44 & 4,14 & $82,8 \%$ & high \\
\hline 7 & $\begin{array}{l}\text { I do not feel undifferentiated in any } \\
\text { case with my work colleagues }\end{array}$ & 11 & 27 & 3 & 3 & & 44 & 3,98 & $79,6 \%$ & high enough \\
\hline \multicolumn{11}{|c|}{ Availability of working facilities } \\
\hline 1 & $\begin{array}{l}\text { Bathroom facilities in the form of } \\
\text { work in the environment in the } \\
\text { company is very supportive }\end{array}$ & 12 & 27 & 5 & & & 44 & 4,16 & 83,2 & high \\
\hline 2 & $\begin{array}{l}\text { Cafe facilities provided by the } \\
\text { company strongly supports the need to } \\
\text { eat and drink employee. }\end{array}$ & 12 & 24 & 3 & 1 & 4 & 44 & 3,89 & $77,8 \%$ & high enough \\
\hline
\end{tabular}




\begin{tabular}{|c|l|c|c|c|c|c|c|c|c|c|}
\hline 3 & $\begin{array}{l}\text { Office stationery supplies available so } \\
\text { complete that can support employee } \\
\text { performance }\end{array}$ & 14 & 26 & 4 & & & 44 & 4,23 & $84,6 \%$ & high \\
\hline 4 & $\begin{array}{l}\text { A place for rest provided in a special } \\
\text { room }\end{array}$ & 12 & 26 & 6 & & & 44 & 4,14 & $82,8 \%$ & high \\
\hline 5 & $\begin{array}{l}\text { Places of worship facilities provided } \\
\text { by the company really helped me to } \\
\text { worship }\end{array}$ & 16 & 24 & 4 & & & 44 & 4,27 & $85,4 \%$ & high \\
\hline 6 & $\begin{array}{l}\text { Internet support facilities greatly } \\
\text { assist employees in finding } \\
\text { information related to the job duties. }\end{array}$ & 13 & 26 & 4 & 1 & & 44 & 4,16 & $83,2 \%$ & high \\
\hline 7 & $\begin{array}{l}\text { Each employee table contained in the } \\
\text { computer equipment to support } \\
\text { employee performance }\end{array}$ & 16 & 25 & 3 & & & 44 & 4,30 & $86 \%$ & high \\
\hline 8 & $\begin{array}{l}\text { Air conditioning as the air conditioner } \\
\text { can support the work of employees }\end{array}$ & 10 & 24 & 7 & 3 & & 44 & 3,86 & $77,2 \%$ & high enough \\
\hline 9 & $\begin{array}{l}\text { Parking facilities helped me park the } \\
\text { vehicle with ease, orderly and safe so } \\
\text { I was comfortable in the environment } \\
\text { agency }\end{array}$ & 11 & 26 & 3 & 3 & 1 & 44 & & 3,98 & $79,6 \%$ \\
\hline
\end{tabular}

Source: Data processed by SPSS 16

From the Table 2 above, the descriptions of respondents to variable working environment above the highest value on the indicator facility tersediannya work item Question 7 that "Each employee table contained in the computer equipment to support employee performance" which based on the total achievement of $86 \%$ of respondents that considered high. It means working facilities each employee table contained in computer equipment to support the employee's performance. The lowest value on the work item suasan indicator question number 1 is "Ifeel hygiene in the Bureau of the Regional Secretariat of the Organization of West Sumatera province create a pleasant working atmosphere" which based on the total achievement of the respondents by $75 \%$ so categorized, including quite high. That is the cleanliness of the Bureau of the Regional Secretariat of the Organization of West Sumatera province creates a pleasant working atmosphere. Of the average value of 4.04 with $80.71 \%$ TCR that includes a high categorized in accordance with the theory according Ahyari in [1], suggests two senses that is a working environment is an environment where these employees work, while working conditions are a condition in which the employee works. According to Simanjuntak in [13], define the working environment as everything that is around the workers who can influence him in carrying out the tasks entrusted. According Sedarmayanti in [12] suggests the working environment is a whole tool tooling and materials are encountered, the surrounding environment where a person works, the method works, as well as the arrangement works both as individuals and as a group.

Table 3: Description of respondents answers against employee performance

\begin{tabular}{|c|c|c|c|c|c|c|c|c|c|c|}
\hline & & \multicolumn{5}{|c|}{ SCORE } & \multirow[b]{2}{*}{$\mathrm{Ttl}$} & \multirow[b]{2}{*}{ Mean } & \multirow[b]{2}{*}{ TCR } & \multirow[b]{2}{*}{ KET } \\
\hline & & $\begin{array}{c}\mathrm{SS} \\
5\end{array}$ & $\begin{array}{l}S \\
4\end{array}$ & $\begin{array}{c}\mathrm{KS} \\
3\end{array}$ & $\begin{array}{c}\mathrm{TS} \\
3\end{array}$ & $\begin{array}{c}\text { STS } \\
1\end{array}$ & & & & \\
\hline No & Performance (Y) & & & & & & & & & \\
\hline \multicolumn{11}{|c|}{ Quality } \\
\hline 1 & I am doing a job with the full calculation & 9 & 32 & 3 & & & 44 & 4,14 & $82,8 \%$ & high \\
\hline 2 & $\begin{array}{l}\text { I have skills in accordance with the work } \\
\text { I am doing }\end{array}$ & 5 & 24 & 15 & & & 44 & 3,77 & $75,4 \%$ & $\begin{array}{l}\text { high } \\
\text { enough }\end{array}$ \\
\hline 3 & $\begin{array}{l}\text { With the ability I have, I am able to } \\
\text { perform the job well. }\end{array}$ & 12 & 26 & 6 & & & 44 & 4,14 & $82,8 \%$ & high \\
\hline
\end{tabular}




\begin{tabular}{|c|c|c|c|c|c|c|c|c|c|c|}
\hline 4 & $\begin{array}{l}\text { I can master the task of other } \\
\text { departments. }\end{array}$ & 11 & 26 & 7 & & & 44 & 4,09 & $81,8 \%$ & high \\
\hline 5 & $\begin{array}{l}\text { I would master the tasks that I am } \\
\text { working with the skill I have }\end{array}$ & 13 & 26 & 5 & & & 44 & 4,18 & $83,6 \%$ & high \\
\hline 6 & $\begin{array}{l}\text { I am reliable in carrying out the work } \\
\text { procedure }\end{array}$ & 10 & 29 & 5 & & & 44 & 4,11 & $82,2 \%$ & high \\
\hline 7 & $\begin{array}{l}\text { I am looking for looking for another job } \\
\text { when I deadlocked }\end{array}$ & 10 & 28 & 6 & & & 44 & 4,09 & $81,8 \%$ & high \\
\hline 8 & $\begin{array}{l}\text { I can quickly adapt to every decision - a } \\
\text { new decision taken by the company }\end{array}$ & 10 & 29 & 5 & & & 44 & 4,11 & $82,2 \%$ & high \\
\hline \multicolumn{11}{|c|}{ Quantity } \\
\hline 1 & $\begin{array}{l}\text { The level of achievement of the volume } \\
\text { of work that I produce in line with } \\
\text { expectations of the Bureau of the } \\
\text { Regional Secretariat of the Organization } \\
\text { of West Sumatera Province }\end{array}$ & 10 & 26 & 8 & & & 44 & 4,05 & $81 \%$ & high \\
\hline 2 & $\begin{array}{l}\text { To produce a job I am proactive in } \\
\text { searching for new working procedures }\end{array}$ & 8 & 28 & 8 & & & 44 & 4,00 & $80 \%$ & high \\
\hline 3 & $\begin{array}{l}\text { Employees can do the job properly and } \\
\text { in accordance with company standards }\end{array}$ & 5 & 24 & 9 & 3 & 3 & 44 & 3,57 & $71,4 \%$ & $\begin{array}{l}\text { high } \\
\text { enough }\end{array}$ \\
\hline 4 & Employees can finish the work on time & 10 & 28 & 6 & & & 44 & 4,09 & $81,8 \%$ & high \\
\hline 5 & $\begin{array}{l}\text { In carrying out the task of the work is } \\
\text { not done } \\
\text { Careful and can be completed. }\end{array}$ & 6 & 31 & 7 & & & 44 & 3,98 & $79,6 \%$ & $\begin{array}{l}\text { high } \\
\text { enough }\end{array}$ \\
\hline 6 & $\begin{array}{l}\text { My work was never blamed by the boss } \\
\text { this is the result of my performance } \\
\text { quality }\end{array}$ & 10 & 29 & 5 & & & 44 & 4,11 & $82,2 \%$ & high \\
\hline 7 & $\begin{array}{l}\text { I have never been late to work this } \\
\text { shows that I have the potential to my } \\
\text { performance }\end{array}$ & 13 & 27 & 4 & & & 44 & 4,20 & $84 \%$ & high \\
\hline 8 & $\begin{array}{l}\text { I showed the quantity of labor in } \\
\text { accordance with the specified target } \\
\text { agency so that my performance be } \\
\text { qualified }\end{array}$ & 9 & 31 & 4 & & & 44 & 4,11 & $82,2 \%$ & high \\
\hline \multicolumn{7}{|c|}{$\begin{array}{rr} & \text { Score } \\
\end{array}$} & & 4,05 & $80,9 \%$ & high \\
\hline
\end{tabular}

Source: Data processed by SPSS 16

From the Table 3 above, the descriptions of respondents to variable employee performance above the highest value on the indicator quantity on item Question 7 that "I was never late to work this shows that I have the potential to my performance" based on the total achievement of the respondents by $84 \%$ thus categorized as high From the table descriptions of respondents to variable employee performance above the highest value on the indicator quantity on item Question 7 that "I was never late to work this shows that I have the potential to my performance" based on the total achievement of the respondents by $84 \%$ thus categorized as high. It means that an employee is never late to work this case indicates that the employee has the potential to performance. The lowest value on quantity indicators on item Question 3 i.e. "Employees can do the job properly and in accordance with the standards of the company" based on the total achievement of $71.4 \%$ of respondents that is considered quite high. Meaning Employees can execute work process properly and in accordance with a predetermined standard. $\mathrm{n}$ accordance with the theory of Hasibuan in [20] states work performance or achievement is a person of work achieved in performing duties assigned to him based on skills, experience, and determination as well as time. Simanjuntak in [13] states that the definition of performance is the level of achievement for the implementation of certain tasks. According Mangkunagara in [6], that the definition of the performance is the result of the quality and quantity of work achieved by an employee in carrying out their duties in accordance with the responsibilities given to him. According Wirawan in [21], the performance is often also referred to as the kinetics of the work or 
performance, the performance is also a function of the results or what someone achieves employees and competition that could explain how employees can achieve these results, in other words the performance is the result of work. According to Mathis and Jackson (2002: 78), referring to the achievements of employee performance is measured based on the standards or criteria established companies. Understanding the performance or work performance is defined as a person's success in carrying out a job.

\subsection{Multiple Linear Regression Test}

Based on the calculation of multiple linear regressions analysis which is done through statistics using SPSS 16, the obtained results are presented in Table 4 as follows:

Table 4: Multiple linear regression test coefficients ${ }^{\mathrm{a}}$

\begin{tabular}{|c|c|c|c|c|c|}
\hline \multirow{2}{*}{ Model } & \multicolumn{2}{|c|}{$\begin{array}{l}\text { Unstandardized } \\
\text { Coefficients }\end{array}$} & \multirow{2}{*}{$\begin{array}{c}\text { Standardized } \\
\text { Coefficients }\end{array}$} & \multirow[t]{2}{*}{$\mathrm{t}$} & \multirow[t]{2}{*}{ Sig. } \\
\hline & B & Std. Error & & & \\
\hline Constant & 53.633 & 24.147 & & 2.221 & 0.032 \\
\hline $\begin{array}{l}\text { Variable (X1) - } \\
\text { Working motivation }\end{array}$ & 1.624 & 0.219 & 0.758 & 7.425 & 0.000 \\
\hline $\begin{array}{l}\text { Variable (X2) - } \\
\text { Working environment }\end{array}$ & 1.618 & 0.281 & 0.601 & 1.965 & 0.004 \\
\hline
\end{tabular}

Dependent Variable: Variabel $(Y)$ i.e. Employee Performance

Source: Data Processed With SPSS 16

Thus, the regression model is derived as follow:

$$
Y=53,633+1,624 X_{1}+1,618 X_{2}
$$

a. Constant 53,633

Constant value of 53.633 indicates that without Working motivation and Working Environment, the Employee Performance has reached 53.633.

b. Variable working motivation $\left(X_{1}\right)$

Working motivation coefficient value of 1,624 which states that an increasing of one unit every working motivation to raise employee performance amounted to 1,624.

c. Working Environment Variables $\left(X_{2}\right)$

Working environment coefficient values indicate a figure of 1.618 which states that if there is an increasing of one unit of the Working environment Employee Performance raise at 1.618.

\subsection{Hypothesis testing}

\subsubsection{T Test}

The test is used to test whether each independent variable significantly influences the dependent variable partially by determining the degree of confidence of $95 \%(\alpha=0.05)$ and also the acceptance or rejection of the hypothesis (See Table 5), then the ways to do are:

a. H0: $\beta=0$, meaning there is no significant influence of independent variables on the dependent variable.

b. Ha: $\beta \neq 0$, meaning no significant influence of independent variables on the dependent variable.

Table 5: $\mathrm{T}$ test coefficients ${ }^{\mathrm{a}}$ 


\begin{tabular}{|c|c|c|c|c|c|}
\hline \multirow{2}{*}{ Model } & \multicolumn{2}{|c|}{$\begin{array}{l}\text { Unstandardized } \\
\text { Coefficients }\end{array}$} & \multirow{2}{*}{$\begin{array}{c}\text { Standardized } \\
\text { Coefficients }\end{array}$} & \multirow[t]{2}{*}{$\mathrm{t}$} & \multirow{2}{*}{ Sig. } \\
\hline & B & Std. Error & & & \\
\hline Constant & 53.633 & 24.147 & & 2.221 & 0.032 \\
\hline $\begin{array}{l}\text { Variable (X1) - Working } \\
\text { motivation }\end{array}$ & 1.624 & 0.219 & 0.758 & 7.425 & 0.000 \\
\hline $\begin{array}{l}\text { Variable (X2) - Working } \\
\text { environment }\end{array}$ & 1.618 & 0.281 & 0.601 & 1.965 & 0.004 \\
\hline
\end{tabular}

\subsubsection{Dependent Variable: Variabel (Y) i.e. Employees Bureau Performance}

Based on the partial test results obtained for working motivation variable $t=7.425$ with a significance value of $0.000<0.05$ indicates that motivation significantly influence employee performance. T table with $d f=n-k=44-3=41$, with a value of $t$ table of 1.681 . Thus the $t$ value of 7.425> $1.681 t$ table, then Ho is rejected and Ha accepted. This shows that motivation influence on employee performance Bureau of the Regional Secretariat of the Organization of West Sumatera province. Based on the partial test results for the working environment variables obtained $t$ count $=1.965$ with a significance value of $0.004<0.05$ indicates that the working environment significantly influence employee performance. The $t$ table with $d f=n-k=44-3=41$, with a value of $t$ table of 1.681. Thus the t value of 1.965>1.681 $t$ table, then Ho is rejected and Ha accepted. This shows that the working environment influence on employee performance Bureau of the Regional Secretariat of the Organization of West Sumatera province.

\subsubsection{F Test}

Based on the calculation of multiple linear regression analysis is done through statistics using SPSS 16, the obtained results as follows: Simultaneous test is used to determine the effect of the independent variable motivation and working environment on the dependent variable employee performance together. Based on testing with SPSS version 16 was obtained ANOVA output in the following Table 6.

Table 6: F Test of ANOVA

\begin{tabular}{|l|r|r|r|r|r|}
\hline \multicolumn{1}{|c|}{ Model } & Sum of Squares & \multicolumn{1}{c|}{ Df } & Mean Square & F & \multicolumn{1}{c|}{ Sig. } \\
\hline Regression & 7716.127 & 2 & 3858.064 & 27.591 & $.000^{\text {a }}$ \\
\hline Residual & 5733.032 & 41 & 139.830 & & \\
\hline Total & 13449.159 & 43 & & & \\
\hline
\end{tabular}

Predictors: (Constant), Variable $\left(X_{2}\right)$ Working environment, Variable $\left(X_{1}\right)$ Working motivation Dependent Variable: Variable $(Y)$ Performance Officer

The ANOVA or $\mathrm{F}$ can test in calculating $F$ value of 27.591 with a significance level of 0.000 . Since a significant probability of much less than 0.05 , then Ho is rejected and Ha accepted. This shows that the simultaneous $\mathrm{H} 3$ stating that motivation and working environment at the same time has an influence on the performance of employees of the Bureau of the Regional Secretariat of the Organization of West Sumatera province received.

\subsubsection{Correlation coefficient $(R)$}

Analysis of correlation $(\mathrm{R})$ is used to determine the relationship between two or more independent variables $\left(X_{1}, X_{2}\right)$ on the dependent variable $(Y)$ simultaneously. $\mathrm{R}$ values ranged from 0 to 1 , the value closer to 1 means the relationship stronger, otherwise the value of getting close to 0 , then the relationship is getting weaker. 
Table 7: Correlation coefficient (R) model summary

\begin{tabular}{|c|r|r|r|r|}
\hline Model & $\mathrm{R}$ & R Square & Adjusted R Square & $\begin{array}{c}\text { Std. Error of the } \\
\text { Estimation }\end{array}$ \\
\hline 1 & $.757^{\mathrm{a}}$ & .574 & .553 & 11.825 \\
\hline
\end{tabular}

a. Predictors: (Constant), Variabel (X2) Lingkungan Kerja, Variabel (X1) Motivasi Kerja

b. Source: Data processed with SPSS 16

Results of the analysis of correlation $(\mathrm{R})$ as described in Table 7 above was obtained the value of $\mathrm{R}$ of 0.757 , it can be concluded that there is a strong relationship between motivation and Environment Working towards employee performance Bureau of the Regional Secretariat of the Organization of West Sumatera province coefficient of Determination To determine the contribution of motivation and working environment to employee performance can be determined based on the value of Adjusted R Square.

Table 8: Coefficient of determination model summary

\begin{tabular}{|c|r|r|r|r|}
\hline Model & R & R Square & Adjusted R Square & $\begin{array}{c}\text { Std. Error of the } \\
\text { Estimate }\end{array}$ \\
\hline 1 & $.757^{\mathrm{a}}$ & .574 & .553 & 11.825 \\
\hline
\end{tabular}

Predictors: (Constant), Variable $\left(X_{2}\right)$ Working environment, Variable $\left(X_{1}\right)$ Working motivation Source: Data processed with SPSS 16

Based on the table 8 above, the model summary notes that the value of Adjusted $R$ Square of 0.553. Can be interpreted to mean that the variable $X_{1}$ (working motivation) and $X_{2}$ (working environment) has contributed $55.3 \%$ influence to variable $Y$ (the performance of employees) and $44.7 \%$ are influenced by other factors beyond the variables $X_{1}$ (working motivation) and $X_{2}$ (working environment).

\subsection{Discussion of Results}

\subsubsection{Influence Motivation Work To Performance Officer}

Based on the partial test results obtained for working motivation variable $t=7.425$ with a significance value of $0.000<0.05$ indicates that motivation significantly influence employee performance. T table with $\mathrm{df}=\mathrm{n}-\mathrm{k}=44-3=41$, with a value of $\mathrm{t}$ table of 1.681. Thus the $\mathrm{t}$ value of 7.425>1.681 t table, then Ho is rejected and Ha accepted. This shows that motivation influence on employee performance Bureau of the Regional Secretariat of the Organization of West Sumatera province. Understanding motivation according to Hasibuan in [20], the definition of motivation is giving momentum that creates the excitement of a job to get them to cooperate, to work effectively and integrated with all efforts to achieve satisfaction. According Samsuddin in [10], to give an opinion on the definition of motivation is the process from outside influence or push against a person or group of work that they want to implement something that has been set. Motivation is Hasat inside a person that causes the person to act (Robet L. Mathis and John H. Jacson, 2006). According to Robbins in [9], the motivation is the process that will determine the intensity, direction and persistence of individuals in order to achieve the target. According to Handoko [19], the motivation is personal circumstances someone encourages the desire of individuals to undertake certain activities in order to achieve the goal. From the opinion of the 
experts above can be concluded that motivation is one of encouragement or effort that is certainly capable of giving encouragement for someone to achieve a desired goal and needs to the fullest. Effect of Working environment Against Employee Performance, Based on the partial test results for the working environment variables obtained $t$ count $=1.965$ with a significance value of 0.004 $<0.05$ indicates that the working environment significantly influence employee performance. $\mathrm{T}$ table with $\mathrm{df}=\mathrm{n}-\mathrm{k}=44-3=41$, with a value of $\mathrm{t}$ table of 1.681 . Thus the $\mathrm{t}$ value of $1.965>1.681$ $\mathrm{t}$ table, then Ho is rejected and $\mathrm{Ha}$ accepted. This shows that the working environment influence on employee performance Bureau of the Regional Secretariat of the Organization of West Sumatera province. In accordance with the theory Ahyari in [1], suggests two senses that is a working environment is an environment where employees are located, while the working condition is a condition in which the employee works. According According to Nitisemito in [8], define the working environment as everything that is around the workers who can influence him in carrying out the tasks entrusted. According Sedarmayanti in [12], suggests the working environment is a whole tool tooling and materials are encountered, the surrounding environment where a person works, the method works, as well as the arrangement works both as individuals and as a group. According to Robbins in [9], the environment is the institutions or forces outside of potentially affect the performance of the environmental oganisasi formulated into two general environment and special environment. General environment is everything outside the organization which has the potential to affect the organization. The environment in the form of social and technological conditions, while the particular environment is part of the environment that are directly related to the achievement of the goals of an organization. Based on several expert opinions can be concluded that the working environment is a place where employees completed the daily duties that a goal of the organization can be achieved with the maximum. The working environment also is very influential on the performance of employees because if the working environment is good then the employee will be comfortable and if the working environment does not support the employee can not safely and comfortably.

\subsubsection{Influence Motivation Work and Working environment Against Employee Performance}

In the ANOVA or $F$ can test in calculating $F$ value of 27591 with a significance level of 0.000 . Because a significant probability is less than 0.05 , then Ho is rejected and Ha accepted. This shows that the simultaneous $\mathrm{H} 3$ stating that motivation and working environment at the same time has an influence on the performance of employees of the Bureau of the Regional Secretariat of the Organization of West Sumatera Province received. Considering each individual within the agency come from various backgrounds different, it will be very important for agencies see the need and expectations of employees, talent and skills they have, and the employee plans in the future to come. If the agency can find out these things, it will be easier to get employees to the most appropriate position so that it will further enhance the motivation for the employees themselves. The working environment is an important factor in the creation of a productive employee performance because if the working environment is not optimal, and tend to be uncomfortable for employees to self-employee motivation to launch daily work will not run with the maximum. Conversely, if an adequate working environment will be able to improve the performance of employees of the company / the institution.

\section{Conclusion and Recommendation}

This paper studied the influence of working motivation and environment on the employees' bureau performance of organization regional secretariat in West Sumatera. Based on the results of research and discussion, there are several conclusions are as follows:

a. Working motivation variable influence on employee performance Organization Bureau of West Sumatera Provincial Secretariat significantly.

b. Environment variables affect the performance of employees working Organization Bureau of West Sumatera Provincial Secretariat significantly. 
c. Variable working motivation, working environment with the same effect on the performance of employees of the Bureau of the Regional Secretariat of the Organization of West Sumatera province.

Based on the above conclusions, the suggestions can be given writer as an input for the agency are given as follows:

a. In an effort to improve the quality of employee performance, the agency that more give promotion and advancement opportunities and scholarships to potential employees so that employees become the spirit of the work.

b. Agencies need to create a more comfortable working environment again as improve air circulation, adding more air conditioning and storage of goods in order to add the files that exist in the institution can be neatly arranged.

c. For further research is recommended to add other variables.

\section{Acknowledgement}

The authors would like to thanks Universitas Putra Indonesia "YPTK" Padang for supporting this research.

\section{References}

[1] Ahyari, Agus. 2000. Production Management (Production Planning System). Yogyakarta: BPFE

[2] Arikunto, Suharsimi. 2002. Research Procedure: A Practice Approach Revised Edition V. Jakarta: PT. Rineka Reserved

[3] Asrianto, Nur Habib. 2013. Effects of Work and Working environment Motivation on Employee Performance CV. Kalika Integraha Semarang. Technical Report Semarang.

[4] Firnadia, L. 2008. Effect of Motivation on Employee Performance Department of Education and Culture Jepara regency. Technical Report Semarang.

[5] Halim, S.H. 2012. Analysis of Motivation and Working environment on Employee Performance At PT. Sinar Pratama

[6] Mangkunagara, Anwar King. 2004. Human Resource Management Company. Bandung: PT. Teens Rosda paper.

[7] Mathis, Robert L and John H Jackson. 2002. Human Resource Management Volume 2. Jakarta: Grafindo

[8] Nitisemito, Alex S.2000. Personnel Management and Human Resources. Ghalia Indonesia: Jakarta.

[9] Robbins, Stephen. P. 2003. Principles of Organizational Behavior. Jakarta: Erland.

[10] Samsuddin, Sadili. 2006. Human Resource Management. Faithful Reader: Bandung.

[11] Sari, Emilia Noviani Astuti. 2009. Effect of Working environment on Employee Performance Parts prosuksi PT. Glory Industrial Semarang II. Technical Report Semarang

[12] Sedarmayanti. 2001. Human Resources and Work Productivity. Bandung: Mandar Maju.

[13] Simanjuntak, Payaman J. 2005. Management and Job Evaluation. Jakarta: FE UI.

[14] Sugiyono. 2007. Qualitative and Quantitative Research Methods $R \& D$. Bandung: Alfabeta.

[15] Surodilogo, Leonardus Bintoro. 2010. Analysis of Working Environment and Working motivation on Employee Satisfaction PT. Healthy sources of Semarang. Technical Report Semarang

[16] Rigolizzo, M. and Amabile, T., 2015. Entrepreneurial Creativity: The Role of Learning Processes and Work Environment Supports. The Oxford Handbook of Creativity, Innovation, and Entrepreneurship, p.61.

[17] Awan, A. and Tahir, M., 2015. Impact of working environment on employee's productivity: A case study of Banks and Insurance Companies in Pakistan. European Journal of Business and Management, 7(1), pp.329-345. 
[18] Tsai, C.Y., Horng, J.S., Liu, C.H. and Hu, D.C., 2015. Work environment and atmosphere: The role of organizational support in the creativity performance of tourism and hospitality organizations. International Journal of Hospitality Management, 46, pp.26-35.

[19] Swastha, B. and Handoko, H., 2000. Manajemen pemasaran: Analisa perilaku konsumen. BPFE, Yogyakarta.

[20] Hasibuan, Malayu SP. "Organisasi dan motivasi." Jakarta: PT. Bumi Aksara (2003).

[21] Ciptonugroho, Wirawan, et al. "One pot synthesis of WOx/mesoporous-ZrO 2 catalysts for the production of levulinic-acid esters." Journal of Catalysis 340 (2016): 17-29. 